\title{
MODEL KURIKULUM PESANTREN SALAFIYAH DALAM PERSPEKTIF MULTIKULTURAL
}

\author{
Imam Syafe'i \\ syafeiimam6@gmail.com \\ Universitas Islam Negeri Raden Intan Lampung
}

\begin{abstract}
Islamic boarding schools are one of the social religious institutions and Islamic education. In general, all pesantren must have characteristics that are not different, namely an institution whose leaders and caregivers are clerics. One type of boarding school in Indonesia is salafiyah boarding schools with special characteristics, namely salaf (traditional). The learning of classical Islamic books or often called "kitab kuning", is one of the characteristics of the salaf pesantren, especially the works of scholars who have embraced Syafi'iyah ideology which are indeed given in the scope of learning in traditional pesantren whose learning focuses on arrest harfiyah for a certain book (text). Santri is one part of the pesantren elements, there are various social and ethnic strata found in Indonesia, until now there has never been a clash of cultures or fights. An understanding of the views of the people in pesantren seems to have been implemented well, which is likely to be unfamiliar in their texts. The transformation of multicultural education has been integrated in the study of classical texts as well as sourced from normative sources found in the Qur'an and hadith, or through other learning such as PKN which has a multicultural educational content for pesantren which are formal education institutions. An understanding of diversity and eliminating Ika appear clearly in pesantren, there are no discriminatory practices for santri in the learning process or in everyday life, respecting so much ethnic diversity and differences, equality, tolerance and open attitude. Efforts to realize a national education goal through multicultural education / learning in Islamic boarding schools are based more on understanding holistic and constructive Islamic teachings.
\end{abstract}

Keywords: Salafiyah and Multicultural Islamic Boarding School Curriculum

\begin{abstract}
Abstrak
Pesantren merupakan salah satu lembaga sosial keagamaan dan pendidikan Islam. Dilihat dari secara umum, seluruh pesantren pasti memiliki karakteristik yang tidak berbeda, yaitu suatu institusi yang pemimpin dan pengasuhnya bergelar kyai. Salah satu jenis pesantren yang terdapat di Indonesia adalah pesantren salafiyah dengan karakteristik khusus, yaitu salaf (tradisional). Pembelajaran kitab-kitab Islam klasik atau sering disebut "kitab kuning", merupakan salah satu ciri dari pesantren salaf, terutama karya-karya ulama yang memang sudah menganut faham syafi'iyah yang memang diberikan dalam ruang lingkup pembelajaran di pesantren tradisional yang pembelajarannya memfokuskan pada penangkapan harfiyah atas suatu kitab (teks) tertentu. Santri merupakan salah satu bagian dari elemen pesantren terdapat berbagai strata sosial dan suku yang terdapat di Indonesia hingga sekarang ini tidak pernah terjadi benturan budaya maupun perkelahian. Pemahaman tentang pandangan masyarakat di pesantren tampaknya telah terimplementasikan dengan baik yang kemungkinan secara teks mereka kurang familier. Transformasi pendidikan multikultural telah terintegrasi dalam kajian teks-teks klasik serta bersumber dari sumber normatif yang terdapat di Al-Qur'an dan hadis, atau melalui pembelajaran lain seperti PKN yang mempunyai muatan pendidikan multikultural bagi pesantren yang merupakan lembaga pendidikan formal. Pemahaman tentang ke-Bhineka-an dan menghilangkan ke-Ika-an tampak dengan jelas di pesantren, tidak ada praktik-praktik diskriminasi bagi para santri pada proses pembelajaran maupun di kehidupan sehari-hari,
\end{abstract}


menghargai begitu banyaknya keanekaragaman etnis dan perbedaan, persamaan hak, toleransi dan sikap terbuka. Upaya agar terwujudkan dari suatu tujuan pendidikan nasional melalui pendidikan/pembelajaran multikultural di lingkungan pesantren lebih didasarkan kepada pemahaman ajaran Islam yang holistik dan konprehenship.

Kata Kunci : Kurikulum Pesantren Salafiyah dan Multikultural

\section{PENDAHULUAN}

Betapa pentingnya sebuah pendidikan multikultural di Indonesia dijelaskan oleh para ahli pendidikan sejak tahun 2000 melalui simposium, workshop, serta dengan berbagai tulisan di media massa dan cetak. Wacana pentingnya pendidikan multikultural di Indonesia pada umumnya didasarkan dengan dua alasan,yaitu: Pertama, Negara Indonesia merupakan salah satu negara yang memiliki banyak permasalahan yang beragam tentang kelompok keagamaan, etnik, dan eksistesi sosial. Problem tersebut disebabkan karena adanya pengelolaan yang kurang baik terhadap keberadaan multi etnik, multi budaya, serta multi agama yang terdapat di Indonesia. Kedua, adanya penekanan semangat ke-ika-an dari pada semangat ke-bhinneka-an dalam praktik pendidikan di Indonesia. Indikator dari ke-ika-an itu dapat dilihat dari beberapa hal seperti: (1) terjadinya penyeragaman kurikulum dan metode pembelajaran; (2) terjadi sentralisasi dalam pengelolaan pendidikan, yang sarat dengan instruksi, petunjuk, dan pengarahan dari atas; (3) belum adanya proses menghargai dan mengakomodasi perbedaan latar belakang peserta didik yang menyangkut budaya, etnik, bahasa, dan agama; (4) proses pendidikan dan pengajaran agama pada umumnya lebih menekankan sisi keselamatan individu dan kelompoknya sendiri daripada keselamatan orang lain di luar diri dan kelompoknya sendiri; (5) terbatasnya ruang perbedaan pendapat antara guru dengan peserta didik, dan atau antara peserta didik satu dengan peserta didik lainnya; (6) fokus pendidikannya hanya pada pencapaian kemampuan ritual dan keyakinan tauhid; (7) guru lebih sering menasihati peserta didik dengan cara mengancam; (8) guru hanya mengejar standar nilai akademik sehingga kurang memperhatikan budi pekerti dan moralitas anak, serta (9) kecerdasan intelektual peserta didik tidak diimbangi dengan kepekaan sosial dan ketajaman spiritualitas beragama.

Untuk menjalankan itu semua tentunya manusia adalah makhluk pilihan yang dimuliakan oleh Allah dari makhluk ciptaan-Nya yang lainnya, dengan segala keistimewaan yang ada pada manusia, seperti akal manusia yang mampu membedakan antara yang baik dan yang buruk, kemudian memilihnya. Allah SWT menciptakan 
manusia dengan sebaik-baiknya cipta (ahsanutaqwim), dan menundukkan alam semesta baginya agar dia dapat memakmurkan dan memelihara kemudian melestarikan keberlangsungan hidup di alam semesta ini. Dengan hatinya manusia dapat memutuskan sesuatu sesuai dengan petunjuk Robbnya, dengan raganya, diharapkan aktif untuk menciptakan karya besar dan tindakan yang benar, hingga ia tetap pada posisi kemuliaan yang sudah diberikan Allah kepadanya seperti ahsanu taqwim, ulul albab, rabbaniun dan lai-lain. Maka, dengan semua sifat kemuliaan dan semua sifat insaniah yang ada dengan kekurangan dan keterbatasan, Allah SWT menugaskan misi khusus kepada umat manusia untuk menguji dan mengetahui mana yang jujur, beriman dan dusta dalam beragama.(Sada, 2016)

Adapun konsep pendidikan yang telah ditawarkan adalah konsep pendidikan multikultural sebagai pengganti dari konsep pendidikan yang monokultural. Tentang betapa pentingnya pendidikan multikultural ini dalam batas tertentu, tentunya mendapat respon yang sangat positif dari badan eksekutif dan legislatif. Hal ini terbukti dengan diundangkannya Undang-undang Republik Indonesia No. 20 Tahun 2003 tentang Sistem Pendidikan Nasional, yang mengakomodasi nilai-nilai hak asasi manusia dan semangat multikultural (Bab III, pasal 4, ayat 1). Bahkan nilai-nilai tersebut dijadikan sebagai salah satu prinsip penyelenggaraan Pendidikan Nasional, sebagaimana yang termaktub pada Bab III pasal 4, ayat 1: "Pendidikan diselenggarakan secara demokratis dan berkeadilan serta tidak diskriminatif dengan menjunjung tinggi hak asasi manusia, nilai keagamaan, nilai kultural, dan kemajemukan bangsa."

Dalam kurikuluim KTSP (Kurikulum Tingkat Satuan Pendidikan) juga memuat prinsip-pinsippendidikan multikultural.Prinsip yang dimaksud adalah "beragam dan terpadu." Prinsip ini dijelaskan sebagai berikut: "Kurikulum dikembangkan dengan memperhatikan keragaman karakteristik peserta didik, kondisi daerah, jenjang dan jenis pendidikan, serta menghargai dan tidak diskriminatif terhadap perbedaan agama, suku, budaya, adat istiadat, status sosial ekonomi, dan jender. Kurikulum meliputi substansi komponen muatan wajib kurikulum, muatan lokal, dan pengembangan diri secara terpadu, serta disusun dalam keterkaitan dan kesinambungan yang bermakna dan tepat antar substansi"

Berdasarkan penelitian terdahulu, telah dilakukan beberapa penelitian dalam mengkaji berbagai bidang menggunakan perspektif multikultural (Aly, 2012; Mustika, 
2016; Tanzilullah, 2016; Unwanullah, 2012) serta telah dilakukan penelitian dalam menganalisis mutu pesantren salafiyah maupun kurikulum pondok pesantren (Anam, 2014; Hafid, 2017; Mushollin, 2014). Berdasarkan penelitian yang telah dilakukan sebelumnya, keterbaruan dalam penelitian ini terletak pada bagaimana model kurikulum pesantren salafiyah yang dilihat dalam perspektif multikultural.

\section{METODE PENELITIAN}

Jenis penelitian yang digunakan adalah model penelitian kualitatif. Penelitian kualitatif bertujuan memperoleh gambaran seutuhnya mengenai suatu hal menurut pandangan manusia yang diteliti. Penelitian kualitatif berhubungan dengan ide, persepsi, pendapat, atau kepercayaan orang yang diteliti; kesemuanya tidak dapat diukur dengan angka

\section{HASIL KAJIAN DAN PEMBAHASAN}

\section{A. Sekilas Pondok Pesantren Salafiyah}

Pesantren merupakan salah satu lembaga sosial keagamaan yang menjadi sarana pendidikan bagi umat Islam yang ingin mempelajari lebih dalam lagi tentang ilmu-ilmu keagamaan (Mun'im, Zainul, \& Rafiq, 2010). Secara umum, di pesantren memiliki karakteristik yang semua sama, yaitu institusi yang dipimpin dan diasuh oleh kyai dalam satu kompleks yang berciri khas: adanya masjid atau surau sebagai pusat pembelajaran dan asrama santri sebagai tempat tinggal santri (peserta didik), di samping rumah yaitu tempat tinggal kyai, dengan buku "kitab kuning" sebagai buku pegangan.

Menurut Mustofa Bisri di samping ciri lahiriyah tersebut, masih terdapat ciri lain yang menjadikan simbol dari karakter pesantren itu sendiri, yaitu kemandirian dan ketaatan santri (peserta didik) kepada kyai yang sering disinyalir sebagai pengkultusan. Pesantren salafiyah yaitu sebuah pesantren yang mempunyai karakteristik khusus, yaitu salaf (tradisional). Senada dengan pendapat tersebut, Zamakhsyari Dhofier juga mengatakan bahwa ada ciri-ciri dari pesantren salafiyah (tradisional), terutama dalam sistem pembelajarannya yang diajarkan.

Pembelajaran kitab-kitab Islam yang klasik atau kita menyabutnya dengan "kitab kuning", karena ciri dari kitab tersebut kertasnya yang berwarna kuning, terutama karyakarya ulama yang menganut faham syafi'iyah (Dhofier, 1994). Semua ini adalah pembelajaran yang bersifat formal yang memang diberikan di dalam lingkungan 
pesantren yang masih tradisional. Abdurrahman Wahid mencatat bahwa ciri utama dari pengajian pesantren (salafiyah) tradisional ini adalah menyampaikan pembelajarannya yaitu dengan memfokuskan pada penangkapan harfiyah dari kitab (teks) tertentu.

Pendekatan yang digunakan yaitu menyelesaikan pembacaan kitab (teks) tersebut, dan untuk kemudian dilanjutkan dengan pembacaan kitab (teks) lain. Dengan system belajarannya yaitu sorogan yang diberikan dalam pengajian kepada para santri (peserta didik) yang telah benar menguasai pembacaan al-Qur'an. Metode utama sistem pembelajaran dilingkungan pesantren salafiyah (tradisional) adalah sistem bandongan atau sering juga disebut sistem wetonan. Kelompok kelas dari system belajar bandongan ini disebut dengan halaqah yang secara etimologis lingkaran santri (peserta didik), atau dengan sekelompok santri (peserta didik) yang mereka belajar tetap di bawah bimbingan seorang ustadz.(Dhofier, 1994).

Pesantren salafiyah, menurut Mustofa Bisri, umumnya benar-benar milik kyainya. Santri hanya datang dengan membawa bekal hidup untuk hidup sendiri di pesantren. Ada bahkan banyak santri yang untuk hidup di pesantren pun mengikut dengan kyainya. Boleh dikatakan, kyai pesantren salafiyah seperti itu, ibaratnya menginfaqkan diri dan semua miliknya untuk hidup para santri (peserta didik). Beliau memikirkan, mendidik, mengajar dan mendo'akan para santri (peserta didik) tanpa pamrih. Bukan saja para santri (peserta didik) itu mondok dipesantrennya, tetapi juga saat para santri sudah mulai terjun di dalam masyarakat.

Pesantren sebagai lembaga pendidikan Islam yang ada di Indonesia yang pada umumnya melaksanakan berbagai satuan pendidikan-baik dalam bentuk sekolah maupun madrasah, seharusnya menjadikan prinsip pengembangan kurikulum yang bermuatan nilai-nilai multikultural tersebut di dalam kegiatan perencanaan, implementasi, dan evaluasi kurikulumnya. Namun dalam pelaksanaannya, poin ini tidak mudah untuk dilakukan oleh pesantren, terkhusus di pesantren tradisional (salafiyah).

Untuk di Indonesia, pendidikan multikultural yaitu pendidikan yang dapat mencetak peserta didik memiliki kearifan lokal, di samping memiliki jiwa toleransi, atau pun menghasilkan peserta didik yang mempunyai pandangan inklusif, penting untuk direalisasikan dan diaktualisasikan. Pendidikan multikultural ini yang akan mengantarkan dan membangun manusia khususnya di Indonesia yang memiliki jiwa nasionalisme dan akhirnya dapat mempertahankan keutuhan bangsa dari ancaman 
disintegrasi. Apabila diimplementasikan di pendidikan yang bercorak keagamaan, maka pendidikan multikultural dipastikan dapat mengantarkan peserta didik berpaham moderat dan inklusif. Menciptakan masyarakat semacam ini merupakan hal fital bagi bangsa Indonesia yang diketahui penduduknya multi-etnis, multi-agama dan plural. Demikian pula, konsep inovasi dan model kurikulum pesantren ini tentu melihat dari tradisi, sehingga tidak terputusnya sejarah hingga sekarang. Pesantren yang dikenal dengan sebutan salafiyah (tradisional) inilah yang sebenarnya melanjutkan tradisi para ulama klasik yang mengajarkan nilai-nilai toleransi dalam ajaran Islam. Tulisan ini, bertujuan mengekplor pendidikan multikultural melalui lembaga-lembaga pendidikan pesantren tentang program yang ditawarkan, proses, dan evaluasinya terhadap implementasi model pendidikan multikultural pada lembaga pendidikan pondok pesantren.

\section{B. Konsep Multikulturalisme}

Sebelum membahas pendidikan multikulturalisme, terlebih dahulu membahas apa konsep pendidikan merupakan proses transformasi dan internalisasi ilmu pengetahuan dan nilai-nilai Islam pada peserta didik melalui penumbuhan dan pengembangan potensi fitrahnya untuk mencapai keseimbangan dan kesempurnaan hidup dalam segala aspeknya.(Sada, 2015) sehingga memudahkan kita untuk memahami pendidikan multikulturalisme. Hal ini didasarkan bahwa "kerangka konsep tentang masyarakat multikulturalisme tidak terlalu baru di Indonesia, sebab prinsip Indonesia adalah sebagai negara "bhinneka tunggal ika" yang mencerminkan bahwa meskipun Indonesia adalah negera terdiri dari berbagai sukubangsa, etnis dan agama, tetapi terintegrasi dalam keikaan, kesatuan "(Azra, 2005). Artinya Indonesia adalah negara Multikultur. Tetapi konsep multikulturalisme berbeda dengan konsep "keanekaragaman" secara suku atau kebudayaan suku bangsa yang menjadi ciri masyarakat majemuk, karena multikulturalisme menekankan keanekaragaman kebudayaan dalam kesederajatan.

Konsep ini senada dengan apa yang dikemukakan Bloom, bahwa multikulturalisme meliputi sebuah pemahaman, penghargaan dan penilaian atas budaya seseorang dan sebuah penghormatan dan keingintahuan tentang budaya etnis orang lain. Artinya, meliputi sebuah penilaian terhadap kebudayaan-kebudayaan orang lain, bukan dalam arti menyetujui seluruh aspek dari kebudayaan-kebudayaan tersebut, melainkan 
mencoba melihat bagaimana kebudayaan tertentu dapat mengekspresikan nilai bagi anggota-anggotanya sendiri (Amini, 2004) Yang jelas dalam kebudayaan multikultural setiap individu mempunyai kemampuan berinteraksi, meskipun latar belakang kultur masing-masing berbeda, karena sifat manusia antara lain, adalah [1] akomodatif, [2] asosiatif, [3] adaptabel, [4] fleksibel, dan [5] kemauan untuk saling berbagi (Suparlan, 2005)

Inilah menunjukan bahwa keragaman kultur ini mengandung unsur keragaman yang sarat dengan nilai-nilai kearifan.Untuk itu, Pendidikan multikultural harus berusaha untuk mengeliminir atau menghilangkan hal yang selalu menjadi emberio atau mendasari terjadinya konflik, yaitu "[1] prasangka historis, [2] diskriminasi, dan [3] perasaan superioritas in-group feeling yang berlebihan dengan menganggap inferior pihak yang lain [out-group]" (Puwasito, 2003)

Konsep multikulturalisme dipahami sebagai pandangan dunia yang kemudian diwujudkan dalam "politics of recognition". Azyumardi dalam Parekh, dibedakan menjadi lima macam multikulturalisme yaitu:

Pertama, " multikulturalisme isolasionis " yang mengacu kepada masyarakat di mana berbagai kelompok kultural menjalankan hidup secara otonom dan terlibat dalam interaksi yang hanya minimal satu sama lain. Contoh masyarakat yang ada pada sistem "millet" di Turki Usmani atau masyarakat "Amish" di AS. Kelompok ini menerima keragaman, tetapi pada saat yang sama berusaha mempertahankan budaya mereka secara terpisah dari masyarakat lain umumnya.

Kedua, " multikulturalisme akomodatif ", masyarakat plural yang memiliki kultur dominan, membuat penyesuaian dan akomodasi-akomodasi tertentu bagi kebutuhan kultural kaum minoritas. Masyarakat multikultural akomodatif merumuskan dan menerapkan undang-undang, hokum dan ketentuan-ketentuan sensitif secara kultural, dan memberikan kebebasan kepada kaum minoritas untuk mempertahankan dan mengembangkan kebudayaan mereka, sebaliknya kaum minoritas tidak menantang kultur dominan. Model "multikulturalisme akomodatif" ini dapat ditemukan di Inggris, Prancis, dan beberapa negara Eropa lain.

Ketiga,"multikulturalisme otonomis", masyarakat plural di mana kelompok-kelompok kultural utama berusaha mewujudkan kesetaraan [equality] dengan budaya dominan dan menginginkan kehidupan otonom dalam kerangka politik yang secara kolektif dapat 
diterima.

Keempat, "multikulturalisme kritikal" atau "interaktif", masyarakat plural di mana kelompok-kelompok kultural tidak terlalu concern dengan kehidupan kultural otonom, tetapi lebih menuntut penciptaan kultur kolektif yang mencerminkan dan menegaskan perspektif-perspektif distingtif mereka. Menciptakan iklim yang kondusif bagi penciptaan secara bersama-sama sebuah kultur kolektif baru yang egaliter secara genuine. Contohnya, masyarakat Hitam di Amerika Serikat, Inggris dan lain-lain.

Kelima,"multikulturalisme kosmopolitan", berusaha menghapuskan "batas-batas kultural" sama sekali untuk menciptakan sebuah masyarakat di mana setiap individu tidak lagi terikat dan committed kepada budaya tertentu dan sebaliknya. Para pendukung multikulturalisme ini yang sebagian besar adalah intelektual diasporik dan kelompok-kelompok liberal yang memiliki kecenderungan postmodernist dan memandang seluruh budaya sebagai resources yang dapat mereka pilih dan ambil secara bebas (Parekh, 1997)

\section{Pendidikan Multikultural}

Akar kata multikulturalisme adalah kebudayaan. Secara etimologis, multikulturalisme dibentuk dari kata multi (banyak), kultur (budaya), dan isme (aliran/paham). Secara hakiki, dalam kata itu terkandung pengakuan akan martabat manusia yang hidup dalam komunitasnya dengan kebudayaan masing-masing yang unik. Dengan demikian, setiap individu merasa dihargai sekaligus merasa bertanggungjawab untuk hidup bersama komunitasnya. Pengingkaran suatu masyarakat terhadap kebutuhan untuk diakui merupakan akar dari segala ketimpangan dalam berbagai bidang kehidupan (Mahfud, 2009)

Pendidikan multikultural berkaitan dengan isu-isu politik, sosial, kultural, edukasional, dan agama (Tilaar, 2009). Ada empat nilai atau core values dari pendidikan multikultural, yaitu apresiasi terhadap adanya kenyataan pluralitas budaya dalam masyarakat, pengakuan terhadap martabat manusia dan hak asasi manusia, pengembangan tanggungjawab masyarat dunia, dan pengembangan tanggungjawab manusia terhadap planet bumi.(Tilaar, 2009) Pendidikan multikultural diartikan sebagai perspektif yang mengakui realitas politik, sosial, ekonomi yang di alami oleh masingmasing individu dalam pertemuan manusia yang kompleks dan heterogen secara kultural, serta merefleksikan pentingnya budaya, ras, seksualitas dan gender, etnisitas, 
agama, status sosial, dan ekonomi. Secara luas pendidikan multikultural itu mencakup seluruh peserta didik (santri) tanpa membedakan kelompok-kelompoknya seperti: gender, etnik, ras, budaya, strata sosial, dan agama (Mahfud, 2009)

\section{E. Implementasi Pendidikan Multikultural}

Pendidikan multikultural menurut Tilaar, sebaiknya tidak diberikan dalam satu mata pelajaran yang terpisah, tetapi terintegrasi dalam beberapa mata pelajaran yang relevan. Misalnya, mata pelajaran ilmu-ilmu sosial dan bahasa, demikian pula mata pelajaran kewarganegaraan dan pendidikan karakter, yang merupakan wadah untuk menampung program-program pendidikan multikultural. Pendidikan multikultural lebih tepat disebut sebagai suatu proses mata pelajaran. Atau dengan kata lain, dalam lingkungan sekolah pendidikan multikultural merupakan pengembangan budaya pluralisme di dalam kehidupan lingkungan sekolah sebagai institusi masyarakat (Tilaar, 2009)

Selanjutnya pendidikan multikutural dalam pandangan Islam, tidak dapat dipisahkan dari konsep pluralis, sehingga muncul terminologi pendidikan Islam pluralismultikultural. Konstruksi pendidikan semacam ini berorientasi kepada proses penyadaran yang berwawasan pluralis secara agamis, sekaligus berwawasan multikultural. Dalam paradigma yang lebih jauh, konstruksi pendidikan Islam pluralismultikultural dapat diposisikan sebagai bagian dari upaya secara komprehensif dan sistematis untuk mencegah dan menanggulangi konflik etnis agama, radikalisme agama, separatisme, dan integrasi bangsa.Nilai dasar dari konsep pendidikan ini, adalah toleransi (Naim \& Sauqi, 2010)

Multikulturalisme akan menjadi jembatan yang mengakomodasi perbedaan etnik dan budaya dalam masyarakat yang plural. Plural atau keragaman dalam pandangan Islam adalah sesuatu yang sunnatullah. Dari awal diakui bahwa keragaman agama dan budaya dikalangan umat manusia dari zaman dahulu kala hingga sekarang adalah fakta yang tidak mungkin dapat diingkari. Keragaman agama dan budaya dapat juga diungkapkan dalam formula pluralisme agama dan budaya. Sementara itu, al-Qur'an adalah kitab suci yang sejak dini membeberkan keragaman ini berdasarkan kasat mata, karena hal itu merupakan bagian dari yang sudah terintegrasi dengan hakikat penciptaan Allah. 
Dalam Islam, rujukan dalam beragama memang ada satu, yaitu al-Qur'an dan alHadits, namun fenomena menunjukkan bahwa wajah Islam adalah banyak. Ada berbagai macam golongan Islam memang mempunyai ciri khas masing-masing dalam praktik dan amaliyah keagamaan sehingga akhirnya muncul apa yang namanya Islam inklusif dan Islam eklusif. Perbedaan pemikiran kedua kelompok ini tampak sekali. Islam inklusif bercorak tradisional dan moderat sedangkan eklusif cenderung berfikir radikal. Golongan Islam yang tradisional umumnya diwakili oleh NU, dan aqidah mereka tidak dapat dipisahkan dari faham ahlusunnah waljama'ah (Aswaja) yang disebut dengan paham moderat (Qomar, 2002) Pemikiran Aswaja sangat toleransi terhadap pluralisme pemikiran.

Berbagai pemikiran yang ada pada masyarakat muslim mendapatkan pengakuan yang apresiatif. Dalam konteks ini Aswaja sangat responsif terhadap hasil pemikiran berbagai madzhab, bukan saja yang masih eksis ditengah-tengah masyarakat (madzhab Hanafi, Maliki, Syafi'i dan Hambali), melainkan juga terhadap madzhab-madzhab yang pernah lahir, seperti Imam Daud al-Dzahiri, Imam Abdurrahman al-Auza'i, Imam Sufyan al-Tsauri, dan lain-lain (Muhammad, 1999)

\section{F. Tujuan Pendidikan Multikultural}

Tampaknya tidaklah berlebihan kalau dikatakan pesantren pemegang kendali utama dalam perekat bangsa. Hingga kini nyaris belum terdengar lembaga pendidikan pesantren terjadi adu jotos, tawuran antar pondok pesantren atau pesantren dengan sekolah umum lainnya. Meskipun pendidikan multikultural baru-baru ini di dengar dan menjadi konsumsi lembaga dan penggiat pendidikan, pesantren dengan santri yang multi kultur, etnis dan bahasa mampu menyatukan latar belakang santri yang beranekaragaman etnis tersebut.Keragaman dalam konteks Indonesia tersebut sudah merupakan sebuah kenyataan sosiologis dan historis karena bangsa ini dibangun dalam kebhinekaan budaya (multikultural) (Kahmad, 2011)

Dengan ini, pondok pesantren secara implisit telah belajar tentang pendidikan multikultural pada level lembaga, pesantren telah berhasil melaksanakan program dari pendidikan multikultural serta mencapai tujuan. Tujuan dari pendidikan multikultural terdapat dua macam, yakni tujuan awal dan tujuan akhir. Tujuan awal dari pendidikan multikultural yaitu membangun wacana pendidikan itu sendiri, pengambil kebijakan di dalam dunia pendidikan itu sendiri dan peserta didik termasuk santri. Harapannya yaitu 
apabila mereka mempunyai wacana tentang pendidikan multikultural yang baik maka suatu saat nanti mereka tidak hanya mampu untuk merubah pendidikan multikultural tetapi juga mampu untuk menanamkan nilai dari pluralisme, humanisme dan demokrasi secara langsung di sekolah kepada para peserta didiknya (Baidhawy, 2005) Sedangkan tujuan akhir dari pendidikan multikultural adalah peserta didik tidak hanya mampu memahami dan menguasai materi pelajaran yang dipelajarinya akan tetapi diharapkan juga bahwa para peserta didik akan mempunyai karakter yang kuat untuk selalu bersikap demokratis, pluralis dan humanis. Karena ketiga hal itu adalah ruh pendidikan multicultural (Baidhawy, 2005) Sedangkan Menurut Clive Black sebagaimana dikutip oleh Ngainun Naim dan Achmad Sauqi (2010) mengatakan bahwa tujuan dari pendidikan multikultural adalah:

(a).Teaching ethnic" student about their own ethnic culture, including perhaps, heritage language instruction; and (b) Teaching all student about various tradisional cultures, at home and abroad. While such studies can be pursuit in a variety of ways, what is unsually missing is systematic treatment of fundamental issues of cultur and ethnicity; (c) Promoting acceptance of ethnic diversity in society (d) Showing that people of differents religions, races,national background and so on are equel worth (e) Fostering full acceptance and equitable treatment of the etnic sub-cultures associated with different religions, race, national background,etc.in one's own country and in other parts of the world; (f) Helping student to works toward more adequate cultural form, for themselves and for society.

Artinya: (a) Pengajaran siswa dengan etnik tertentu tentang kebudayaan yang mereka miliki, termasuk yang ada di dalamnya pengajaran bahasa pusaka, dan (b) Pengajaran kepada semua siswa tentang keanekaragaman budaya tradisional, baik dalam dan luar negeri. Ketika pembelajaran dapat disampaikan dalam berbagai cara, sesuatu yang tidak biasanya terlewat adalah susunan secara sistematis dari isu utama tentang budaya dan etnisitas bangsa, (c) Mempromosikan penerimaan menunjukkan perbedaan atau keanekaragaman etnik dalam masyarakat (d) bahwa manusia dengan perbedaan agama, ras, suku kebangsaan memiliki kebebasan yang sama. (e) menunjukkan penerimaan secara penuh dan ditanda dengan perlakukan yang sama yakni keseimbangan antara budaya sub ethnic dengan perbedaan agama, ras, suku kebangsaan, dll dalam satu Negara dan di bagian Negara lain di dunia.(f) Membantu 
siswa dalam menyesuaikan bentuk budaya, untuk dirinya sendiri dan untuk masyarakat) (Naim \& Sauqi, 2010)

Dengan demikian, tujuan dari pendidikan multicultural yaitu berupaya untuk mengajak warga tepatnya di pendidikan agar menerima perbedaan yang ada pada manusia sebagai suatu hal yang alamiah (natural sunnatullah). Selain itu, pedidikan multikultural menanamkan jiwa kesadaran kepada peserta didik (santri) akan kesetaraan (equality), keadilan (justice), kemajemukan (plurality), kebangsaan, ras, suku, bahsa, tradisi, penghormatan agama, menghendaki terbangunnya tatanan kehidupan yang seimbang, harmoni, fungsional dan sistematik dan tidak menghendaki terjadinya proses diskriminasi, kemanusiaan (humanity), dan nilai-nilai demokrasi (democration values) yang diperlukan dalam beragam aktivitas sosial

\section{G. Program Pendidikan Multikultural}

Menurut Azyumardi Azra dengan mengutip pendapat Bunnet, Pendidikan multikultural itu sendiri memiliki tiga program yang tentu dapat diterapkan oleh pesantren atau sekolah dan masyarakat secara keseluruhan.

Pertama, program yang berpusat pada materi (content-oriented programs) yang merupakan bentuk dari multikultural yang umum dapat mudah dipahami, yaitu tujuan utamanya adalah memberikan materi tentang kelompok budaya yang berbeda dalam kurikulum dan materi pendidikan dalam rangka meningkatkan pengetahuan siswa mengenai kelompok-kelompok tersebut.

Kedua, program yang berpusat untuk siswa (student-oriented programs) yang dimaksudkan agar meningkatkan prestasi peserta didik di akademik siswa yang berbeda, meskipun mereka tidak dapat memberikan perubahan besar lebih dalam muatan kurikulum.

Ketiga, program yang berorientasi sosial (Sosially-oriented programs) yang berupaya mereformasi pendidikan maupun konteks politik dan budaya pendidikan, yang bertujuan untuk memiliki pengaruh yang sangat signifikan dalam meningkatkan toleransi budaya dan ras serta mengurangi bias diskriminasi. 


\section{H. Proses Pembelajaran Pendidikan Multikultural yang terdapat di pondok Pesantren}

Kegiatan pembelajaran tersebut yang bermuatan pendidikan multikultur di pondok pesantren dirancang agar memberikan pengalaman belajar yang melibatkan suatu proses mental dan fisik melalui interaksi antar peserta didik (santri), peserta didik dengan guru, lingkungan, dan sumber belajar lainnya dalam rangka pencapaian kompetensi dasar. Kegiatan pembelajaran tersebut dapat terwujud dengan melalui penggunaan pendekatan di dalam pembelajaran inkuiri dan tetap berpusat pada peserta didik dengan menerapkan beberapa metode yang sesuai seperti metode diskusi, tanya jawab, bermain peran, penugasan, dan lain sebagainya. Ada beberapa hal yang memang harus diperhatikan dalam mengembangkan suatu kegiatan pembelajaran pendidikan multikultur yaitu: dalam Kegiatan pembelajaran multikultur disusun untuk memberikan bantuan kepada para pendidik (guru), agar dapat tetap melaksanakan pembelajaran secara profesional.

Kegiatan pembelajaran multikultur berisikan rangkaian kegiatan yang harus dilakukan oleh peserta didik itu. Penentuan jadwal kegiatan pembelajaran dengan materi pembelajaran muatan multikultur harus sesuai. Rumusan pernyataan dalam proses pembelajaran yang bermuatan pendidikan multikutur minimal harus terdapat dua unsur yaitu kegiatan peserta didik dengan materi multikultur.

Merumuskan indikator pencapaian kompetensi yang bermuatan multikultur. Indikator yang bermuatan multikultur merupakan penanda pencapaian kompetensi dasar yang ditandai oleh perubahan perilaku yang dapat diukur mencakup sikap, pengetahuan, dan keterampilan yang bermuatan multikultur. Indikator dikembangkan sesuai dengan sifat(katakter) peserta didik (santri), mata pelajaran, satuan pendidikan, lingkungan dan potensi daerah yang dirumuskan dalam kata kerja operasional yang terukur dan/atau dapat diobservasi. Indikator digunakan sebagai dasar untuk menyusun alat penilaian.

\section{Evaluasi Pendidikan Multikultural}

Pendidikan multikultural di pesantren, meskipun telah teruji keberhasilannya, namun secara formal juga perlu dilakukan oleh satuan pendidikan untuk melihat seberapa jauh tingkat keberhasilannya dan hambatan-hambatan dalam pelaksanaan menjadikan suatu pendidikan yang multicultural. Pelaksanaan evaluasi dapat dilakukan sesuai dengan keputusan rapat sekolah atau pesantren, yaitu bisa dilakukan setiap catur 
wulan, setiap akhir semester secara kualitatif untuk digabungkan pada penilaian kepribadian siswa melalui mata pelajaran pendidikan agama Islam di lingkungan Kemendikbud atau pada mata pelajaran agama (Akidah Akhlaq, Al-Qur'an Hadits, SKI dan Bahasa Arab) di lingkungan Kemenag dan mata pelajaran PPKn atau melalui muatan lokal, dalam bentuk pelajaran apa yang tepat dan sesuai dengan muatan pendidikan multikultural.

Penentuan jenis penilaian yang bermuatan multikultur bagi peserta didik dilakukan berdasarkan indikator yang bermuatan multikultur. Penilaian dapat dilakukan dengan menggunakan tes dan non tes dalam bentuk tertulis maupun lisan, pengamatan kinerja, pengamatan prilaku dan pergaulan santri selama ia berstatus menjadi santri di pesantren yang bersangkutan, pengukuran sikap, penilaian hasil karya berupa tugas, proyek dan/atau produk, penggunaan portofolio, dan penilaian diri. Penilaian yang berisikan pendidikan multikultur merupakan proses dari kegiatan untuk dapat memperoleh, menganalisis, dan menafsirkan data dari proses hingga hasil belajar siswa yang dilakukan secara tersusun dan berkesinambungan, sehingga tetap menjadi informasi yang bermakna dalam pengambilan keputusan.

\section{SIMPULAN DAN SARAN}

Sejarah Pendidikan multikultural di Indeonesia tidak sapat dipisahkan dengan keberadaan pondok pesantren. Meskipun tidak secara ekplisit tertera dalam kurikulum pendidikan pesantren, tetapi pengejawantahan prilaku santri telah menunjukkian adanya pendidikan multikultural. Pesantren yang serba multi kultur, etnis, suku, budaya, dan bahasa para santri tidak pernah nmuncul kepermukaan, Yang ada, adalah nilai-nilai kebersamaan, kerukunan, disiplin dan saling menghargai antar sesama santri dengan segala ketaatan dan ketakdzimannya kepada kyai.

Bagi pesantren, ide pokok pendidikan multicultural itu merupakan penguatan secara formal yang selama sudah dilaksanakan. Tujuannya adalah untuk melakukan perubahan pendidikan yang secara telah menyeluruh dan membongkar sisi-sisi kekurangan, kegagalan serta untuk menghindari praktik-praktik diskriminasi bagi para peserta didik(santri) di dalam proses pendidikan sebagai upaya untuk dapat mewujudkan tujuan dari pendidikan nasional itu.

Untuk mewujudkan ide pokok pendidikan multikulturalisme, harus didasari pada konsep ketaqwaan dan iman, keberadaban, sopan, toleran, mandiri, bebas dari 
paksaan, kekerasan, ancaman, keadilan sosial, dan persamaan hak dalam konsep dan praktik-praktik pendidikan. Konsep pendidikan multikulturalisme harus mencoba memfasilitasi dalam proses pembelajaran yang memang harus menghargai keragaman etnis dan perbedaan, persamaan hak, toleransi dan sikap terbuka. Mengembangkan kemampuan untuk mampu hidup mandiri dan mengatur segala tentang diri sendiri tanpa bantuan campur tangan dari pihak lain, bebas dari paksaan, ancaman dan kekerasan sebagai ciri dari pendidikan pesantren dan pendidikan multikultural. 


\section{DAFTAR PUSTAKA}

Aly, A. (2012). Model Kurikulum Pendidikan islam Multikultural Di Pondok Pesantren Modern Islam Assalam Surakarta. Varia Pendidikan, 24(1), 23-33.

Amini, E. I. A. (2004). Analisis Kebutuhan Pendidikan Multikultural Berbasis Kompetensi Pada Siswa Sekolah Lanjutan Tingkat Pertama [SLTP] di Kota Mataram. Program Pascasarjana IKIP Negeri Singaraja.

Anam, K. (2014). Mutu Pesantren Salafiyah Dalam Konteks Penyelenggaraan Pendidikan Nasional. Ta'allum, 2(2), 215-237.

Azra, A. (2005). Identitas dan Krisis Budaya, Membangun Multikulturalisme Indonesia. Retrieved from http://kongres. budpar. go.id /agenda /precongress /makalah /abstrak/58azyumardiazra.htm

Baidhawy, Z. (2005). Pendidikan Agama Berwawasan Multikultural. Jakarta: Erlangga.

Dhofier, Z. (1994). Tradisi Pesantren: Studi tentang Pandangan Hidup Kyai. Jakarta: LP3ES.

Hafid, M. (2017). Pengaruh Motivasi Dan Kompetensi Guru Terhadap Kinerja Guru Sekolah Dan Madrasah Di Lingkungan Pondok Pesantren Salafiyah Syafi'iyah Sukorejo. JPII, 1(2), 293-314.

Kahmad, D. (2011). Multikulturalisme dalam Perspektif Islam. Bandung: Pustaka Al Kasyaf.

Mahfud, C. (2009). Pendidikan Multikultura. Yogyakarta: Pustaka Belajar.

Muhammad, H. (1999). Memahami Sejarah Ahlusunnah Waljama'ah: yang toleran dan anti ekstrem, dalam Imam Baehaqi (ed). Kontroversi Aswaja. Yogyakarta: LKiS.

Mun'im, A., Zainul, \& Rafiq. (2010). Peran Pesantren Dalam Education For All di Era Globalisasi.

Mushollin. (2014). Kurikulum Pondok Pesantren Muadalah. Nuansa, 11(1), 128-150.

Mustika. (2016). Diskriminasi Terhadap Beberapa Perempuan Dalam Perspektif Feminisme Multikultural : Kajian Terhadap Novel Scappa Per Amore Karya Dini Fitria. Jurnal Poetika, IV(1), 33-41.

Naim, N., \& Sauqi, A. (2010). Pendidikan Multikultural Konsep dan Aplikasi. Yogyakarta: Ar-Ruuz Media Grub.

Parekh. (1997). Identitas dan Krisis Budaya, Membangun Multikulturalisme Indonesia. Retrieved from http://kongres.budpar.go.id/ agenda/ precongress/ makalah/abstrak/58 azyumardi azra.htm

Puwasito, A. (2003). Komunikasi Multikultural. Surakarta: Muhammadiyah University Press.

Qomar, M. (2002). NU Liberal: Dari Tradisionalisme Ahlusunnah ke Universalisme 
Islam,. Bandung: Mizan.

Sada, H. J. (2015). Pendidik Dalam Perspektif Al-Qur'an. Al-Tadzkiyyah: Jurnal Pendidikan Islam, 6(1), 93-105.

Sada, H. J. (2016). Manusia Dalam Perspsektif Agama Islam. Al-Tadzkiyyah: Jurnal Pendidikan Islam, 7(1), 129-142.

Suparlan, P. (2005). Menuju Masyarakat Indonesia Yang Multikultural. In Simposium Internasional Jurnal Antropologi Indonesia ke-3. Bali.

Tanzilullah, M. I. (2016). Tahsinu Al-Salah Sebagai Media Spiritual Bimbingan Konseling Perspektif Multikultural. KONSELING RELIGI: Jurnal Bimbingan Konseling Islam, 7(1), 189-208.

Tilaar, H. A. . (2009). Kekuasaan dan Pendidikan: Manajemen Pendidikan Nasional dalam Pusaran Kekuasaan. Jakarta: Rineka Cipta.

Unwanullah, A. (2012). Transformasi Pendidikan Untuk Mengatasi Konflik Masyarakat Dalam Perspektif Multikultural. Jurnal Pembangunan Pendidikan: Fondasi Dan Aplikasi, 1(1), 45-57. 